\begin{tabular}{rr} 
çağdaş & Yaratıcı Drama Dergisi 2015, 10(1), 63-74 \\
drama & www.yader.org \\
\hline
\end{tabular}

\title{
Dansın Çocuk ve Gençlerle Kurduğu İletişimin Niteliği: Estetik Mesafe, Özdeşleşme ve Estetik Deneyim
}

\author{
Bilge Serdar ${ }^{1}$
}

\begin{tabular}{|c|c|}
\hline Makale Bilgisi & $\ddot{O} z$ \\
\hline DOI: $10.21612 /$ yader.2015.006 & Her sanat dalı kendine has nitelikleriyle seyircisine diğer sanat dallarından farklı \\
\hline $\begin{array}{l}\text { Anahtar Sözcükler } \\
\text { Dans } \\
\text { Estetik mesafe özdeşleşme } \\
\text { Estetik deneyim } \\
\text { Kinestetik iletişim }\end{array}$ & 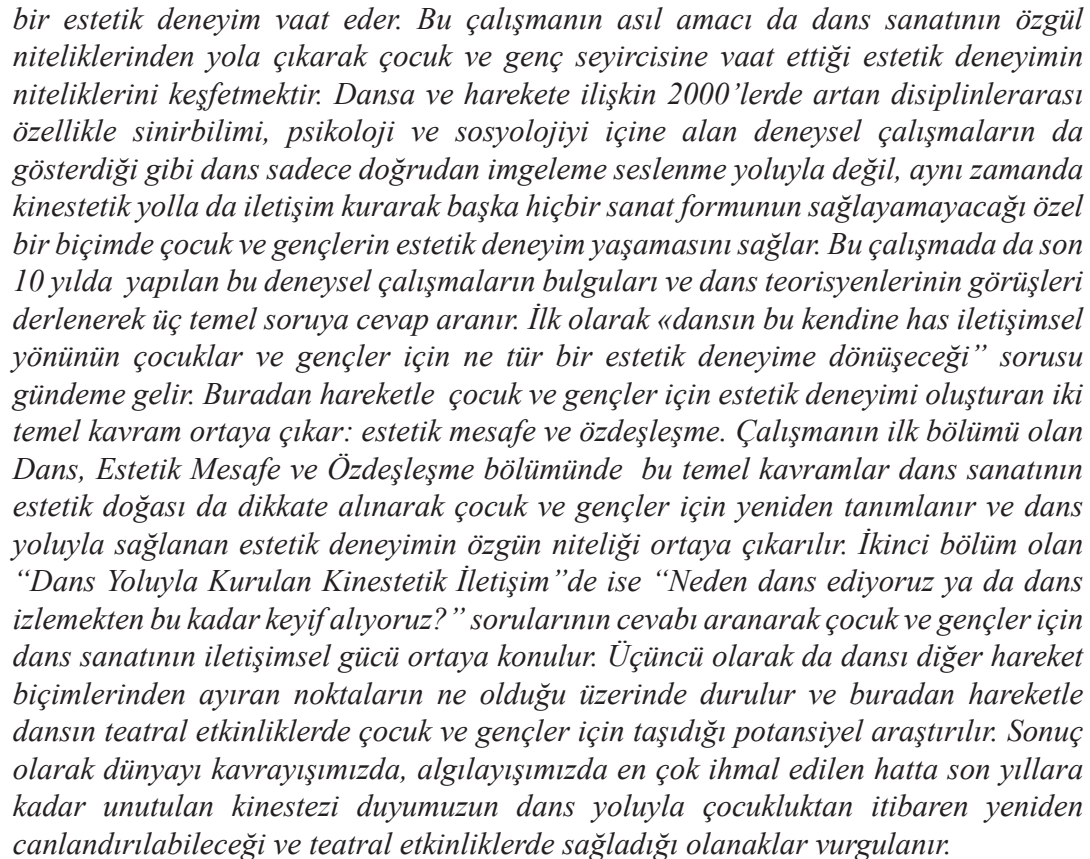 \\
\hline
\end{tabular}

\section{The Quality of Relationship Between Dance and Children and Youth: Aesthetic Distance, Identification and Aesthetic Experience}

\begin{tabular}{l} 
Article Info \\
\hline DOI: $10.21612 /$ yader.2015.006 \\
\hline Keywords \\
Dance \\
Aesthetic distance \\
Identification \\
Aesthetic experience \\
Kineshtetic communication
\end{tabular}

Kineshtetic communication

\begin{abstract}
Each field of art commit a different type of aesthetic experience to own audience from others by its own idiosyncracy. The main porpuse of this research is to discover these idiosyncracy aesthtetic experince of dance which was committed to their children and youth audiences. As it's shown by experimental interdisciplinary researchs about dance and movement which involve neuroscience, psychology and sociology in 2000's, dance not only connect with our immagination but also enable children and youth to get aesthetic experience in a idiosyncratic way through kinesthetic communication. In this paper I focused on three main questions as compiling the results of researchs and arguments of dance theoretician in last 10 years. First of these questions is "what is the role of dance played by its idiosyncratic ways of kinesthetic communication in children and youth's aesthetic experience?" Accordingly, two essential concepts are
\end{abstract}


generated which composed the aesthetic experience for children and youth: aesthetic distance and identification. These essential concepts are re-described for children and youth as considering characteristics of them in the first chapter, Dance, Aesthetic Distance and Identification. And the idiosyncratic ways of communication of dance in the relationship between dance and children is unfold. Second chapter Kinesthetic Communication through Dance is try to answer the questions of "why we are dancing?" or "how and why we like watching dance?" and produce the communication ability of dance for children and youth. Finally, it's dwelled on which charactheristcs distinguish dance from other movement styles and based on this it's emphasised that potantial of dance in theatre for young audience. As a result in this paper it is emphasized that we can ensoul our kinesthetic sense which is ignored especially in recent years as from our childhood. Thus the importance of the possibilities of dance in creative drama and in theatre for young audience is exhibited.

\section{Giriş}

\section{Dans, Estetik Mesafe ve Özdeşleşme}

Çocuk ve gençlik tiyatrosunda çocuğun yaşayacağı karşılaşmanın estetik deneyime dönüşmesi için performansın kurgusal doğasını kabul etmesi zorunludur. Bu da ancak performans ve genç seyirci arasındaki estetik mesafe ile mümkündür. Bu kabul, temel teatral konvansiyonlardan biridir. Estetik mesafe kavramı ise bizi diğer bir önemli noktaya yani özdeşleşme kavramına götürür. Özdeşleşme, sadece estetik mesafenin bir sonucu olarak önem kazanmaz, aynı zamanda çocuk ve gençlerin gelişim süreçlerinin doğal bir parçası olduğu için de estetik deneyimin niteliğini belirleyen unsurlarından biri haline gelir.

\section{a) Dans-Genç Seyirci İlişkkisinde Kurulan Estetik Mesafenin Niteliği ${ }^{2}$}

Mesafe kavramı, Bullough'un estetik deneyimi açıklarken kendi benliğimizle bir çeşit kaynak ya da aracı görevi gören nesneler arasındaki ${ }^{3}$ ilişkiyi açıklamak için kullandığı bir çeşit metafordur. Estetik takdir ancak bu mesafe sinırının ötesinde y a da bu mesafe sinırının içinde mümkündür". "Yani her hangi bir sanat eseriyle karşılaşan alımlayıcı bu sanat eserini kendi deneyimlerinin dünyasından yani gerçek hayattan ayıramadığı takdirde bu sanat eserinden estetik deneyim elde edemeyecektir. Buradaki merkezi ilke hem izleyici hem sanatçı için aynıdır. Hedef aşırı özdeşleşmeye dalmaksızın işin içine en üst düzeyde dahil olmaktır. Eğer uzaklık kaybolursa sanat da kaybolur. ${ }^{5}$ Bollough bu bağlamda mesafeye ilişkin iki uç koşul tanımlamış olur: Aşırı yakın mesafe (under-distancing) özne ham bir biçimde doğalcı, gerçekçiliğiyle itici ve insanın içini oyucu olduğu zaman ortaya çıkarken, aşırı uzak mesafede (over-distancing) üslup bir yapaylık, uyumsuzluk, boşluk ya da saçmalık izlenimi yarattığg zaman ortaya çıkar. ${ }^{6}$

İnsanı malzeme olarak kullanan tüm teatral formlar -opera, dans, tiyatro vb.- seyircisiyle beden aracılığıyla ilişki kurduğundan kurgusallı̆̆ 1 dolayısıyla mesafeyi yaratma konusunda aynı zorluğu paylaşırlar. Yine de bu teatral performanslardan en çok dans bu zorluğu yaşar. Dans çok daha güçlü bir biçimde aşıı yakın mesafenin ayartıcılığını yapar çünkü dansın hayvansal tabiatı tinselliğin hiçbir zerresiyle dindirilemez. ${ }^{7}$

2 İlk kez estetik mesafenin zamansal veya fiziksel mesafenin ötesinde bir şey olduğu 1912'de Edward Bullogh'un Sanat ve Estetik Prensipte Bir Faktör Olarak Fiziksel Mesafe adlı makalesinde vurgulanır.

3 Gerald C. Cupchik The Evolution of Psychical Distance as an Aesthetic Concept/ Estetik Bir Konsept Olarak Fiziksel Mesafenin Evrimi, Culture Psychology , June 2002 vol. 8,no. 2, s.155-187

4 R. Naversen,a.g.e

5 G. C. Cupchik, a.g.e

6 G. C. Cupchik, a.g.e

7 G. C. Cupchik,a.g.e 
Ancak söz konusu olan seyirci, genç seyirciler olduğunda -özellikle daha küçük yaştaki seyirciler için- bu mesafenin önemi estetik hazzın artması ya da azalmasının ötesine geçer. Çünkü etişkin seyircinin sahip olduğu ön kabuller özellikle daha küçük yaştaki seyirciler için söz konusu değildir. Yani gerçek hayatla kurgu dünyası arasındaki mesafeyi algılayamayan çocuk, gerçek hayatla sahne arasındaki ayrımı anlamakta da zorlanacaktır. ${ }^{8}$ Bu zorluktan yola çıkarak Theatre for Children and Young People: Images and Observations adlı kitabında Schonamnn', Bollough'un kavramlarından hareketle genç seyirciler için üç farklı mesafe biçimi tanımlar:

1. Yakın mesafe (Low distance): Çocuk kurguya çok fazla daldırılmıştır ve yaratılan hayali dünyayı yaşadığı gerçek dünyadan ayıramaz. Sahnedeki olaylara müdahale etmeye çalışır, ağlar, sesli güler ya da kendini sahnedeki dünyaya fazlasıyla kaptırır.

2. Uzak mesafe (High distance): Çocuk performanstan tamamen koparılmıştır ve yarat1lan kurgusal dünyanın içinde değildir. Salonun içinde dolaşır, yanındaki yetişkinle ya da arkadaşlarıyla oyunla ilgisi olmayan konuşmalar yapar. Oyuna dair hiçbir duyusal ifade göstermez.

3. İdeal mesafe (Optimal distance): Çocuk katılımını uygun mesafede gösterir ve bu sanatsal estetik hazla sonuçlanır. Konsantre olmuş bir biçimde oyunu izler, yanındakilerle oyuna dair konuşmalar yapar, oyundaki anlara uygun tepkiler verir. ${ }^{10}$

$\mathrm{Bu}$ üç tip mesafeden yola çıkarak genç seyirciler için temel sorunun çocuğun ya gereğinden fazla özdeşleşmesi ya da hiç özdeşleşememesi olduğunu rahatlıkla söyleyebiliriz. Bu bir dans performansına uyarlandığında çocuk seyirci için kurgu dünyasının fark edilememesi durumu kendiliğinden ortadan kalkar. Çünkü dans hareketleri her ne kadar günlük hayatla ilişkilendirilebilirse de günlük hayattaki hareket biçimlerinden belirgin biçimde ayrılır. Aslında bir dans performansında da kurgu vardır, özellikle bu performans bir hikayeyi anlatıyorsa. Ancak kurgu bir dans performansında dansçının kendi uzmanlığını ve becerisini gösterdiği performansın gerçekliğinde temellenir. ${ }^{11}$ Başka bir deyişle, bir dans performansında bir hikâye anlatılıyor ya da bir duygu ifade ediliyorken ya da sadece dansçı kendi hünerini sergiliyorken dansçının bedeninin sarf ettiği efor, genç seyirciyi kurgu dünyasına götürse de ya da kendi hayal gücüyle baş başa bıraksa da asla genç seyircinin kendini kurgu dünyasına tamamen kaptırmasına izin vermez. Çünkü bu esnada dansçı ani dönüşler, sıçramalar yapar, bedenini farklı biçimlere sokar, seyirciyi şaşırtır. Yani beden daha önce de belirtildiği gibi bir yandan bizi bu kurgusal dünyaya çekerken bir yandan da sergilediği hareketlerin günlük hareketlerimizden farklılığı, esnekliği, gücü, dengesi ile bizim oradalığımızı canlı tutar. Bu durumda çocuk seyirci için gereğinden fazla özdeşleşme durumu ortadan kalkar. Ancak bu, özdeşleşmenin tamamen ortadan kalkması demek değildir. Çünkü özdeşleşmenin anahtarı, kişinin kendisiyle bir ilişkiyi fark etmesidir. ${ }^{12} \mathrm{Bu}$ durumda özdeşleşme, herhangi bir performansta sadece karakterle özdeşleşme yoluyla gerçekleşmez. Dansta her hareket, sıradan deneyimden ne kadar uzak olursa olsun, yine de sıradan deneyimle bağlantılı bir izlenim verir. Dansçının deneyimini kendi içinde üreten izleyicinin bedeninde kinestetik bir yanıt vardır. ${ }^{13}$ Yani seyirci, dansçıyla kendi bedeni arasında oluşan ilişki yoluyla bu özdeşleşmeyi sağlayabilir. Aynı durum çocuklar için de geçerlidir. Bir dans performansı izleyen çocuklar sık sık dansçıların esnekliğinden ve yükselişlerinden etkilenirler. Terleme ve nefes

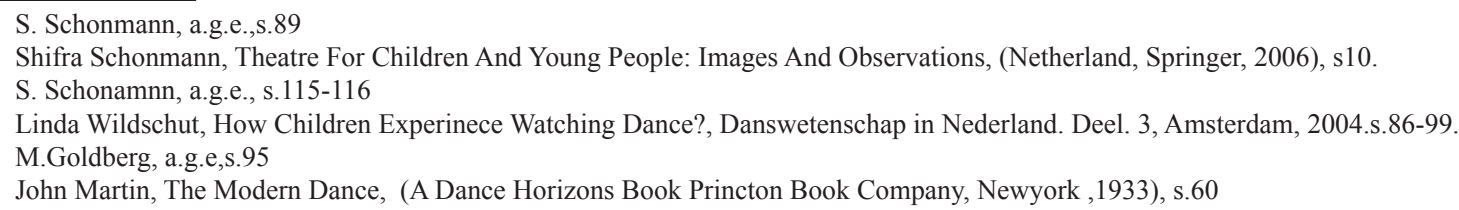


alma sesini bunların gerçek insanların performansı olduğuna kanıt olarak görünür ve aslında bir dans performansinda çocuklar bu yolla 'özdeşleşme ' kurarlar. $^{14}$

\section{b) Dans Yoluyla Özdeşleşme}

Çocuk ve ergen gelişimi açısından psikologların ve eğitimcilerin sık sık vurgu yaptığ özdeşleşme, sıklıkla normal gelişim süreci içindeki çocuk ya da ergenin benliğine örnek olarak seçtiği kişi veya kişilere benzemeye çalışması olarak tanımlanır. ${ }^{15}$ Aynı zamanda özdeşleşme kavramı bir önceki bölümde de belirtildiği gibi genç seyircinin teatral bir etkinlikte edindiği estetik deneyimde, kurulan estetik mesafeye bağlı olarak önemli bir yer tutar. Ancak optimal mesafe sınırları içinde gerçekleşen optimal bir özdeşleşme yoluyla genç seyircinin estetik haz alması mümkündür. Özdeşleşmenin estetik deneyimle olan yakın ilişkisi empati kavramının estetikle olan bağından kaynaklanır.

Genç seyirci için optimal mesafe sınırları içinde bir özdeşleşme, dans içerikli bir performansta tiyatroda olduğundan daha farklı gerçekleşir. Tiyatroda çocuğun karakterle kurduğu ilişki söz konusuyken bir dans performansında bu ilişki ikili bir şekilde işler. Burada durum, bu performansın soyut dans ya da bir öykü içeren anlatı dansı olması durumuna bağlı olarak değişir. Çünkü anlatı dansında çocuğun hem anlatılan öyküdeki karakterle hem de dansçıyla özdeşleşmesi söz konusudur. Soyut dansta ise anlatılan bir öyküye bağlı bir karakterin yokluğu çocuğu dansçıyla baş başa bırakır ve çocuk dansçıyla özdeşleşir. Yani kısaca bir dans performansında iki türlü özdeşleşmeden söz edilebilir: karakterle özdeşleşme ve dansçıyla özdeşleşme.

Dans izleme deneyimini irdeleyen çalışmalar sayıca az olmasına rağmen Hollandalı bir dansçı ve akademisyen olan Leisbeth Wildschut'1n How Children Experince Watching Dance? adlı çalışması özellikle genç seyircinin dans izleme deneyimini odağına aldığı için dikkate değerdir. Leisbeth Wildschut çalışmasında on ile on dört yaş arasındaki 391 çocukla yaptığı bir çalışmayı anlatır. Bir kısmı dans deneyimi olan ve bir kısmı da dans deneyimi olmayan bu bir grup çocuğa biri anlatı dansı ve diğeri de soyut dans olmak üzere iki tip performans izleten Wildschut ilginç sonuçlara varır. $\mathrm{Bu}$ araştırmada Wildschut, dans deneyimi olan çocukların dans deneyimi olmayan çocuklara göre dansçılarla daha çok özdeşleşmesini bekler ancak Wildschut'un bu hipotezi tam olarak doğrulanmaz. Çünkü on yaşındaki çocuklarla on yaş üstü çocukların tepkilerini ayrı ayrı değerlendiren Wildschut dans deneyiminin sadece on yaş üstü çocuklarda belirgin bir farklılık yarattığı sonucuyla karşılaşır. Daha küçük çocuklarda dans deneyiminin olup olmaması danş̧ılarla özdeşleşmede fark yaratmaz. Yani başka bir ifadeyle daha küçük çocuklar dans deneyimine bağlı olmaksızın dansçılarla aynı oranda özdeşleşirler. Wildschut'a göre bu durum arzu temelli özdeşleşmeden kaynaklanır. Arzu temelli özdeşleşme gerçek kişiliklerle değil, hayal edilmiş benzerlik üzerine kuruludur. Arzuya bağlı özdeşleşmede hayal edilebilir, yani çocuğun geçmişte dans deneyiminin olması özdeşleşme derecesini etkilemez. Ona göre seyirci için sahnenin cazibesi sahne üzerinde olma arzusuna ya da teknik olarak becerili olmaya temellenmiş olabilir. $\mathrm{Bu}$ durumda bu arzu benzerlerin deneyimine sebep olur. Yani Wildschut'a göre daha genç çocuklar arasında dans deneyiminin belirgin bir farklılık yaratmaması, özdeşleşmenin arzu temelli bir özdeşleşme olduğunu gösterir ve bu sonuç, arzu temelli özdeşleşmenin bir dans gösterisi izleyen daha küçük yaştaki çocuklarda dansçıyla özdeşleşmede daha büyük yaştaki çocuklarda olduğundan daha çok etkili olduğunun bir göstergesidir.

14 L. Wildschut, a.g.e,

15 Engin Geçtan, Çağdaș Yașam ve Normal Dıșı Davranıșlar, (İst., Maya Yay. , 1984), s. 171. 
Wildschut'ın çalışmasından çıkan bu sonuçlar Johannes Volkelt'in empati çözümlemesi ile tutarlıdır. Volkelt empatiyi iki türe ayırır. Birinci tür empati, insanın öbür insanlarla ve sanat yapıtlarıla olan ilgisinde ortaya çıkar ve bu ilgi ruhsal- duygusal ortaklık üzerine kuruludur. Volkelt buna ortak duygudaşlık ilgisi der. Bu tür empatide bir insanı ya da sanat yapıtını seyreden, onu algılayan süjenin algıladığı varlıkta empatilediği şey ile algıladığı şey arasında bir örtüşme meydana gelir ${ }^{16}$. Öyleyse rahatlıkla bir çocuğun -hatta yetişkinlerin- performansta izlediği karakterle özdeşleşmesinin bu tip bir özdeşleşmeye dahil olduğu sonucunu çıkarabiliriz. İkinci tür özdeşleşme ise ruhsal- sembolik empatidir. Burada algılanan şey ile özdeşleşilen şey arasında daima kapanmayan bir yarık söz konusudur, bir uyum ve örtüşme yoktur. Ruhsal-sembolik empatiye örnek olarak bir çınar ağacı karşısında duyduğumuz yücelik duygusunu örnek olarak gösterilebilir. Aslında Volkelt'in ruhsal-sembolik empatisi Wildschut'1n arzu temelli özdeşleşmesiyle örtüşür. Daha küçük çocuklarla yapılan araştırmada dans deneyimi olan çocukların da en az dans deneyimi olmayan çocuklar kadar dansçılarla özdeşleşme kurmaları bu tip bir özdeşleşmeye girer. Dansçıların sahne üzerinde gösterdikleri performans, yani dönüşleri, sıçramaları, en zor hareketleri hiç zorlanmadan yapıyormuş gibi görünmeleri, kısaca sahne üzerindeki hünerleri çocukta hayranlık duygusu uyandırarak dansçılarla ruhsal sembolik ya da diğer bir deyişle arzu temelli özdeşleşme sağlar.

Wildschut'ın araştırmasından çıkan bu veriler aslında şu önemli sonucu çıkarmamıza da izin verir: Hem soyut dans hem de anlatı dansı üzerinde yapılan araştırmalarda her iki tür performansta da özdeşleşmenin gerçekleştiği bilgisi, bizi dansın bir hikâye olmaksızın dahi seyircisiyle özdeşleşme yaratabileceği sonucuna götürür. Bir başka deyişle dans, bir hikâye anlatmasa bile kendi başına genç seyirciyle özdeşleşme yoluyla ilişki kurabilir. Üstelik bu sonuç farklı yaş gruplarındaki tüm çocuklar için doğrulanır ve daha küçük yaştaki çocuklar için dansın özellikle bir hikâye anlatmıyorsa fazla soyut olabileceği şeklindeki yaygın kanıyı da böylelikle çürütmüş olur.

Wildschut'ın araştırmasından çıkan asıl ilginç sonuç ise çocukların dansçılarla karakterle olduğundan daha fazla özdeşleştikleri sonucudur. Buna göre tüm katılımcı çocuklar -özellikle daha küçük yaşta olanlar- hem soyut dansta hem de anlatı dansında dansçılarla karakterlerle olduğundan daha fazla özdeşim kurarlar. Yani Wildschut'a göre bu araştırmanın sonuçları çocukların karakterlerin kurgusal dünyasıyla belli oranda özdeşleştiğini ancak dansçıların gerçek dünyasıyla daha güçlü özdeşleştiklerini göstermiştir. Her ne kadar bu araştırmadan çıkan sonuçlar Wildschut'ın seçtiği performansların içeriğiyle ilgili olsa da dansçının gerçek bedeninin karakterin kurgusal yapısının önüne geçerek çocukla daha yakın bir ilişki kurduğu, herhangi bir dans performansı için de rahatlıkla genelleyebileceğimiz bir sonuçtur. Başka bir deyişle; dansçı karakterin önüne geçer. Bu da bizi, dansın genç seyircileri nasıl böyle güçlü bir biçimde etkilediği sorusuna yöneltir. Bu sorunun cevabı, aslında özdeşleşmenin fiziksel doğasında gizlidir. Özdeşleşmenin fiziksel doğasına değinmek, dans yoluyla seyircinin nasıl özdeşleştiğine dair kavrayışımızı tamamlar.

$\mathrm{Bu}$ konuda dans dünyasına fikirleriyle ilham veren kişi Alman düşünür Theodor Lipps olur. Lipps 1900'lerin başında Einfühlung yani empati kavramını ortaya attığında sadece estetikle empati kavramlarını ilişkilendirmekle kalmaz, aynı zamanda empati kavramının fiziksel yönüne de vurgu yapar. Böylelikle dans araştırmacılarının dans, estetik ve empati kavramları arasındaki yeni araştırmalarına ön ayak olur. Lipps'e göre hareket halindeki bir objeyi izlemek, kişiye bu objenin hareketlerini taklit etme eğilimini hissettirir. Kişi gerçekten bu hareketleri yapmaz, ancak

16 İsmail Tunalı, a.g.e, 42 
hareketleri taklit etme niyetini ya da eğilimini deneyimler. Bu eğilimler kinestetik algıyı yaratır ki bunlar duygularla bağlantılıdır. ${ }^{17}$

Aslında kinestezi terimi Yunanca "kine" (hareket) ve "estesiz" (duyu, duyulamak) kelimelerinden oluşur ve bu bağlamda "kişinin kendi hareketlerinin duyusu" anlamına gelir. ${ }^{18}$ Ayrica ilk olarak on dokuzuncu yüzy1l sonundaki fizyolojik incelemelerde bedenin hareketlerini duyulamayı ifade etmek için kullanılmıştır. ${ }^{19}$ Yirminci yüzyılın henüz başlarında psikolojideki yeni atılımlar, yapılan algı çalışmaları, kas ve sinir sistemiyle ilgili yeni araştırmalar ve tüm bunların sonuçları dans dünyasındaki eğilimleri de etkiler.

John Martin özellikle 1930'larla 1960'lar arasında dansla seyirci arasındaki ilişkiyle ve bir dans izleyicisinin edindiği deneyimlerle ilgili yaptığı çalışmalarla yirminci yüzyılın modern dansına yön veren isimlerin başında gelir. Martin, dansın ikili yapısına yani fiziksel ve psişik yapısına metakinesis der. Martin'e göre bedensel hareketin doğal bulaşıcılığından ötürü, ki bu durum bakan kişiyi kendi kas sisteminde de başka birinin kas sisteminde gördüğü şeyi sempatik bir biçimde hissetmesi sonucunu çıkartır, dansçı hareket yoluyla en ele avuca gelmez duygusal deneyimi aktarabilir. Böylelikle Martin aslında modern dansın da temel felsefesini ifade etmiş olur.

Yani aslında dansla seyirci arasındaki bu bağ, dansçının bedeniyle seyircinin bedeni arasında kinesteziye yani hareket duyumuna bağlı olarak kurulan ve iç taklit yoluyla dansçıyla özdeşleşmemiz sonucunu doğuran bir bağdır. Bu durum aslında bizi dans eden birini izlerken doğal olarak o kişiyle özdeşleştiğimiz sonucuna götürür. Buradan da neden Wildschut'ın araştırmasında tüm çocukların dansçılarla karakterlerle olduğundan daha fazla özdeşleştiğinin cevabına ulaşırız. Yani genç seyircinin teatral bir performansla kurduğu ilişki sadece karakterlerle kurduğu özdeşleşme üzerinden gerçekleşmez. Aynı zamanda kendi bedeni yoluyla da bu özdeşleşme sağlanabilir. Goldberg'in de belirttiği gibi özdeşleşmenin anahtarı kişinin kendisiyle bir ilişkiyi fark etmesidir. ${ }^{20} \mathrm{Bu}$ açıdan bakıldığında dans yoluyla sağlanan bu çeşit bir özdeşleşme de genç seyircinin yaşayacağı estetik deneyimde önemli hale gelir.

\section{Dans Yoluyla Kurulan Kinestetik İletişim}

Dans iletişim kurar çünkü içimizdeki tepkileri harekete geçirir. Dans basit bir görsel sanat değildir, aynı zamanda kinestetiktir, hareketimizin içsel duyularını cezp eder. ${ }^{21}$ İşte bu kinestetik iletişim, dansı bir sanat formu olarak özel kılan şeydir ve burada sadece dansın sağlayabileceği özel estetik bir tatmin duygusu söz konusudur. Dansın bu başka bir dille ifade edilemeyen doğası empatik bilinçaltımıza yönelir. Böylelikle dans seyircisiyle hem doğrudan iletişim kurar hem de bilinçaltımıza seslenerek dolaylı bir iletişim sağlar. Dolayısıyla dans, hareket yoluyla aynı anda pek çok anlamı iletme gücüne sahip olur. ${ }^{22}$

Dansın bu diğer sanat dalları tarafından sağlanamayan kinestetik iletişimsel yönü yirminci yüzyıldan itibaren araştırılmaya başlanmıştır. Susan Leigh Foster Movement's Contagion: The

17 Linde van Heeswijk, The Relation Between Dance, Music And Expectation Choreographing Surprise, Thesis MA Theatre Studies Utrecht University, Temmuz, 2010.

18 Mary M. Smith, Kinesthetic Communication in Dance, Dance Research Journal, Vol. 16, No. 2 (Autumn, 1984 ), s. 19-22.

19 Susan Leigh Foster Movement's Contagion: The Kinesthetic Impact Of Performance, Cambridge Companion To Performance Studies, June ,12, 2008.

20 M. Goldberg, a.g.e,s.95

21 M. Smith,a.g.e

22 M. Smith, a.g.e 
Kinesthetic Impact Of Performance ${ }^{23}$ adlı makalesinde bir dans performansının seyircisiyle girdiği kinestetik etkileşime dair, sinirbilimi ve psikoloji alanının araştırma bulgularına bağlı olarak değişen yaklaşımları inceler. Kinestezi kavramına ilişkin görüşleri üç başlık altında toplar: ilk görüş, dans izleme deneyiminde kinestetik olarak bir şeyle iç içe geçmenin duygusal bir bağlantı ortaya çıkardığını varsayar; ikinci görüş, hareketin sadece kendi fiziksel olgusallığı yüzünden beğenilebileceğini umut eder; üçüncü görüşte ise bir dansı izlemenin olası yaylar ve akışları sürekli olarak bir araya getirme beklentisi ortaya çıkardığı varsayılır. Bu son kinestezi kavrayışında koreograf gibi izleyici de hareket hakkında düşünür ve bir sonraki hareketin nereye gideceğine karar vermeye çalışır. $\mathrm{Bu}$ danslar izleyicide çeşitli duygulanımlar ve hisler ortaya çıkartır. Yani seyirci, koreografın dansı ortaya çıkarmasına benzer şeyleri deneyimler. Bu şekilde de koreografın niyeti, seyirciye geçmiş olur.

Foster'ın bu makalesi özetle bir performansı izlediğimizde bu deneyimimizin nasıl gerçekleştiğine dair üç farklı yaklaşım ortaya koymuş olur: Kinestezi yani hareket duyumuz bu üç farklı yaklaşıma refereansla içselleştime görevi de görebilir, bizim çevreyle uyumumuzu da sağlayabilir ya da bizi hareket etmeye ya da hareketin devamını tahmin etmeye de yönlendirebilir. Tüm bu farklı kinestezi kavrayışları bir dans performansı izleme deneyiminde seyircilerin sadece birer izleyici değil, aynı zamanda genç seyirciler için özellikle onemli olan performansın ortak girişimcileri olduğunu da ortaya koyar. Yani sadece kendi hareketimiz değil başkalarının hareketleri de kinestezi duyumuz yoluyla bizi bir grubun parçası yapar. Ve modern dünyada belki yağmur yağdırmak için toplu olarak dans etme yoluyla değil ama dans ederek ya da bir dans izleyicisi olarak kinestezi duyumuzu geliştirebiliriz.

Bir seyircinin dans deneyimini tam olarak kavramak ve bu deneyimin ortaya çıkardığı hazzın özelliklerini belirlemek nörobilimsel çalışmaların yanında seyirci araştırmalarını da gerektirir. $\mathrm{Bu}$ çalışmaların en önemlilerinden biri de Wacthing Dance: Kinesthetic Empathy ${ }^{24}$ adl1 2008-2011 yılları arasında gerçekleştirilen seyirci araştırmalarını ve nörobilimi temel alan, dansın seyircileri nasıl etkilediği ve dansla nasıl özdeşleşildiğini araştıran disiplinlerarası bir projedir. ${ }^{25} \mathrm{Bu}$ çalışmada seyircilerin herhangi bir dans performansı izleme deneyimlerine gösterdikleri ortak tepkiler arastirilir. $\mathrm{Bu}$ tepkilerin ustalık isteyen bir dans sergilendiğindeki hayrete düşmenin eğlencesini, kendini dans ederken hayal etmenin hazzını, kendini bir diğerinin bedeninde keşfetme problemini, sarf edilen eforla bağlantılı olan duyusal tepkiyi, dansın güçlüğünü ve zorluğunu, hoş hareketlerin moral verici ve mutluluk verici duygularının tadını çıkaran hayalperest tepkileri, uyarıcı boyunca uyum ve uyumsuzluğu araştıran çoklu algı tepkilerini ve izleme süreci yoluyla değişen seyircinin nefes alması, duruşu, ve enerjisinden oluşan somutlaştırılmış tepkileri' ${ }^{26}$ içerdiği tespit edilir.

$\mathrm{Bu}$ tepkiler daha iyi analiz edilebilmek için şu üç kategoriye ayr1lırlar: kinestetik yayılım, kinestetik sempati, kinestetik empati. Makalede özellikle iç taklit ya da hayal edilmiş yerine koyma anlarında, kendi ve başkası arasında dışavurulan deneyimler ve hayali deneyimler, kinestetik empati terimiyle değerlendirilebilir. Bilişsel ve yansıtıcı tepkiler -başkalarının ustalığına hayran olmak, çabayı takdir etmek ya da hareketin üzerindeki duygusal niyeti yansıtmak gibi- ise kinestetik sempati olarak değerlendirilirler. Bu her ikisiyle de bağlantılı olan seyirci ve gösteri arasındaki bir çeşit

23 S.L.Foster, a.g.e

24 www.watchingdance.org

25 Matthew Reason ve Dee Reynolds bu projenin verilerini Kinesthesia, Empathy and Related Pleasures: An Inquiry into Audience Response adlı makalede bir araya getirirler

26 M.Reason, D.Reynolds ,a.g.e 
tepki ise kinestetik yayılım kategorisine alınır. Yani seyircilerin tutkuyla sevindirici ve mutluluk verici hareketlerdeki hoşa giden haz duygusunu tanımlamaları, dansa anlık duyusal durumlarda verdikleri tepkiler kinestetik yayllım olarak tanımlanabileceği gibi bunun dışında seyircilerin kendi kalp atışlarını ve nefes alma hareketlerini kendi hareket algılarıyla, muhtemelen bunun dışında işitsel algıları özellikle müzik ve dansçının nefes alışlarıyla senkronik olarak yaptıklarını fark etmeleri de kinestetik yayılım kapsamında değerlendirilir. Kısaca seyirciler bir dans izleme deneyimi yaşarken başkalarının hareketlerinin onları bedensel olarak, duygusal olarak ve hayali olarak etkilediğini dile getirmiş olurlar.

Özellikle genç seyirciler için yapılan bu tip nitel alan çalışmaları yeni olsa da önceki bölümlerde sözü edilen Leisbeth Wildschut'ın çalışması bir dans performansında genç seyircinin edindiği deneyime ilişkin yukarıda sözü edilen çalışmaları tamamlar nitelikte sonuçlar elde eder. Daha önce de adı geçen How Children Experince Watching Dance? adlı çalışmasında Wildschut sadece genç seyircilerin karakterle olduğu kadar dansçılarla da özdeşleştiği sonucunu çıkarmaz. Aynı zamanda genç seyircilerin dans performansına katılımlarını da gözlemleyen Wildschut bu konuda da önemli olan ve Reason ve Reynolds'ın çalışmalarını genç seyirciler açısından tamamlayan bir takım sonuçlara varır. Wildschut genç seyircilerin bir dans performansında farkında olmadan dansçıların hareketlerine, kafalarıyla kolları ya da bacaklarıyla eşlik ettiklerini gözlemler.

Gerek anlatı dansında gerek soyut dansta on yaşındaki çocukların tümü performansa eşit derecede katılım göstermişlerdir. İkinci önemli sonuca göre de soyut dansta yaşa ya da çocukların dans deneyimine bağlı olmaksızın tüm çocuklar performansa belirgin bir farklılık göstermeden eşit katılım sağlamışlardır. Diğer bir sonuca göre de anlatı dansında on yaş üstü çocuklarda deneyime bağl1 olarak böyle bir farklılık mevcuttur. Wildschut'a göre soyut dansta koreograf hareket yapılarına vurgu yaptığı için çocukların dikkati dans deneyimi olsun ya da olmasın harekete odaklanır. Ancak söz konusu olan bir anlatı dansı olduğunda koreograf karakterlerin deneyimlerine dikkat çekerken her ne kadar hareketi temel alsa da hareket dışında pek çok gösterge kullanır. Bu durumda Wildschut'a göre harekete odaklanmaya karar veren seyircidir ve dans deneyimi olan on yaş üstü çocuklar hareket hafızalarına bağlı olarak anlatı dansında harekete odaklandıklarından daha fazla katılım gösterirler.

Wildschut'ın kinestetik katılımla ilgili vardığı bu sonuçlar çocuklar için yapılan teatral bir performansta hikâyenin vazgeçilmezliğini sorgulama gerekliliğini ortaya çıkarır. Sözü edilen tüm bu araştırmalar bir dans performansının ister hikâye odaklı olsun ister olmasın doğrudan bize görsel, işitsel ve kinestetik olarak haz verme gücü olduğunu kanıtlar. Üstelik Wildschut'ın bu çalışması çocukların bir karaktere gerek duymadan dans izleme deneyimlerini özdeşleşme ve kinestetik katılım yoluyla estetik bir performansa dönüştürebileceğini gösterir. Dans eden birini izlediğimizde onu neden ilgiyle izlediğimizin biyolojik temellerinin altını çizer ve neden dansçılarla özdeşleştiğimize son derece bilimsel yollarla cevap verir. Ancak her zaman bu kinestetik etkileşim estetik deneyime dönüşmeyebilir. Bu nedenle dansın kendine has estetiksel niteliği de bu deneyimde incelenmesi gereken diğer bir başlik olarak belirir.

\section{Dansın Estetik Doğası}

Dans ile genç seyirci ilişkisini yapılandırırken bir önceki bölümde dansın seyirciyle hangi yollarla iletişim kurduğu ayrıntılandırılmıştır. Ancak izleyicide bu dans deneyiminin sadece 
duyusal bir deneyim olarak kalmayıp estetik deneyime dönüşmesi için dansın içeriğine dair de bazı noktaların ayrıntılandırılması gerekir. Nasıl görme ve işitme tartışmasız bir biçimde estetik duyular olarak tanımlanırken izlediğimiz her oyun, baktığımız her resim ya da dinlediğimiz her müzik bize haz vermiyorsa, izlediğimiz her dans da bizim biyolojik olarak ilgimizi çekse de bize estetik haz vermeyebilir. Bu durumda dansı diğer hareket biçimlerinden ayıran ve onu estetik kılan niteliklerinin belirlenmesi, estetik deneyimin tamamlanması açısından önem kazanır.

Dans kuramcıları, dansın kendine özgü niteliğini tanımlamaya çalışırken pek çok noktada uzlaşırlar. Dansın günlük hayattaki hareket biçimlerinden hatta ritmik diğer hareket biçimlerinden ayıran özellikler üzerinde dururlar. Bu kuramcılardan Susan Langer'a göre ilk insanın doğayla ve insanüstü güçlerle başa çıkma aracı olan dans, hâlâ aynı gücü içinde barındırır. Bu güç sanal güçlerdir. ${ }^{27}$ Ona göre dansın bu öncelikli yanılsaması çoğunluğun tanımladığı gibi ritmik hareket olamaz. Ritmik hareket, dansın fiili sürecidir. Ona göre her sanat dalında gerçeklik nasıl dönüşüyorsa danstaki bu hareketin gerçekliği de dönüşümün sancısını çekmelidir. Hareketler dans yoluyla jestlere ama sanal jestlere dönüşerek bu dönüşümü yaşamalıdır. McFee ise dansin estetize edilmiş özel çeşit bir hareket ${ }^{28}$ olduğunu kabul eder ancak onun için dans, estetize hareket olsa da bildirisel değildir. Bu nedenle bu estetize etme bir 'dönüştürme' içermelidir. $\mathrm{O}$, bu fark1 anlatmak için günlük hareketlerimizden yola çıkar ve süpürme hareketini ele alır. Bir kişi elinde bir süpürgeyle yerleri zarif, seçkin, akışkan bir biçimde süpürdüğünde ona bakan kişi bu zarifliğe, çizgiye yani süpürme hareketine konsantre olur ve hareketin amaçsal boyutunu kaybeder. Aslında süpürme hareketi, eylemi yapan kişi tarafindan gerçekten estetize edilmiştir, ancak bu durum süpürme hareketini dans yapmaz, hareket hâlâ süpürme hareketidir. McFee'ye göre eğer süpürme hareketi bir dans motifinin içine yerleştirilirse ve bu şekilde estetize edilirse ancak süpürme hareketi olmaktan çıkar ve artık bir dans hareketine dönüşür. Ona göre bu dönüştürme işlemi bir hareketi dans sanatı bağlamı içinde değerlendirmemizi sağlar, çünkü bu dönüştürme işlemi o harekete ilgi, önem ve değer yükler ki bunlar da sanatla ilgilidir. Mary Wigman'a göre ise dansı oluşturan, jestlerin birbirine bağlandığ hareketin oluşma biçimidir: bir hareketin önceki hareketten nasıl doğduğudur ve bir sonraki harekete organik olarak geçme biçimidir. Ona göre jimnastik ile dansı birbirinden ayıran en önemli fark bu bağlanma biçimleridir. ${ }^{29}$ Selma Jeanne Cohen, dans etmenin kendi aşkına ve kendi çıkarına hatta kendi anlam ilgisinin üzerinde olmak üzere tasarlanmış hareket olarak düşünülebileceğinin altını çizer. Pandomim sanatçısının hareketlerini ilginç kılanın da bu olduğunu dile getirir çünkü her bir hareketinin bir anlamı vardır. Ama tam da bu yüzden dansçının hareketlerinden farklıdır. Ona göre mimi ya da pandomimciyi dikkatli izlememizin sebebi, yaptığı hareketleri saptamaktır. Tam da bu noktada bu ilgiyi Cohen, anlam ilgisi (interest of meaning) olarak tanımlar. Mimin hareketlerini anlayamaz olduğumuzda artık bu gösteriden zevk almaz oluruz. Ama bir balerinin hareketlerini anlamını saptama ihtiyacı duymaksın zevkle izleyebiliriz. ${ }^{30}$

Langer, McFee, Wigman ve Cohen'in açıklamalarından dansın herhangi bir durumu, hareketi dönüş̧ürerek estetize ettiğini, yani dansın aslında gerçek durumları değil gerçeğin imgelemlerini dansçının bedeni yoluyla -dansçının sanal jestleri yoluyla- yansıttığını aynı zamanda bu jestlerin

27 S. Langer, Virtual Powers, What Is Dance?, Edited By: Roger Copeland, Marshall Cohen, ( New York, Oxford Universty Press, 1983)

28 Graham McFee, Understanding Dance, (London, Routledge,1992), s.51.

29 Mary Wigman, Modern Dansın Felsefesi, Yirminci Yüzyılda Dans Sanatı 'Kuram ve Pratik' Yayına Hazırlayanlar: Şebnem Selışık Aksan, Gurur Ertem, , (İstanbul, Boğaziçi Üniversitesi Yayınları, ,2009) s.95

30 M. Wigman,a.g.e 
birbirine bağlanma yolunun onu diğer günlük hareketlerimizden ayırdığını, son olarak da bütün bunların toplamında dansın aslında bir anlam çıkarından bağımsız olduğunu yani bir anlama gerek duymaksızın bizi etkileme gücü olduğu sonucu çıkartılabilir. Tüm bunlar bizi genç seyirci için dansın sahip olduğu potansiyel açısından iki temel noktaya taşır. Bunlardan ilki zaten daha önce ayrıntılı bir biçimde ele alınan ve estetik deneyimin kilit noktasını oluşturan estetik mesafe kavramıyla ilişkilendirilebilir. Dans; 'gerçeği' koreografın, yönetmenin ya da dansçının (aslında son kertede yine de dansçının) imgelemi yoluyla süzer. Son olarak bizim sahne üzerinde gördüğümüz gerçeğin ta kendisi değil onun imgeleminin bedensel yollarla ifadesidir. Dans, gerçeği estetize ederek dönüştürdüğü için genç seyirciyi optimal mesafede tutma gücüne sahip olur. Daha başka bir ifadeyle beden bir yandan çocuğun gereğinden fazla özdeşleşme yaşamasına zemin hazırlarken, bir yandan da gündelik yaşantıyı, hareketleri dönüştürüp estetize ettiği için kurgusal dünyayla gerçek dünyanın birbirine karışma riskini ortadan kaldırır. Ancak elbette dönüştürme işlemi koreografın, dansçının ya da yönetmenin kullandığı üsluba bağlı olarak bu estetik mesafeyi azaltabilir de arttırabilir de.

$\mathrm{Bu}$ dans betimlemelerinin bizi ulaştırdığı ikinci bir önemli sonuç da dansın yukarıda sözü edilen olanaklarıyla -çocuk ve gençlik tiyatrosunda tabu olarak ya da zor olarak kabul edilen konuları işlemeyi olanaklı kılmasıdır. Örneğin ‘ölüm', çocuk ve gençlik tiyatrosunda bir tabu olarak kabul edilir. ${ }^{31}$ Ölümü konu edinen çalışmalarda ise ölüm, tanrı imgesiyle beraber kimi zaman gerçekçi figürler yanında, sembolik figürlerle ${ }^{32}$ temsil edilir, kimi zaman çocuğun duyusal uyuşmasını kolaylaştıracak ${ }^{33}$ şekilde ölüm temasının farklı yönlerine vurgu yapılarak işlenir, kimi zamanda ölüm duygusunun kasvetli ortamından oyunu kurtarmak için müzik ve 1şık yardımıyla farklı bir atmosfer yaratılır. Bu farklı yollarla ölüm teması dönüştürülerek sahnede üzerine getirilir. Tanrı konusu da tıpkı ölüm gibi tabu olan konulardan biridir. Schonmann, genç seyirciler için yapılan tiyatroda bilinmezlerin teatral temsilleri için biçimsel arayışların yerine bu bilinmezlerin zihinsel imgelerinin nasıl yaratılabileceğinin düşünülmesi gerektiğinden söz eder ve hem genç seyircilerin hayal gücünü bloke etmediğimizden; hem de Tanrı kavramıyla ilgilenirken ortaya çıkan derin düşünceleri yok etmediğimizden emin olmamız gerektiğinin altını çizer. ${ }^{34}$

Tam da bu noktada dansın az önce sözü edilen niteliklerini yeniden vurgulamak gerekir. Dansın anlam çıkarının üzerinde olması, yani bir anlama ihtiyaç duymaksızın bizi etkilemesi, dansı duyular dünyasına, duygulara ve dolayısıyla imgeler dünyasına yaklaştırır. Dolayısıyla bu tabu konular işlenirken ihtiyaç duyulan zihinsel imge arayışına karşılık gelir. Dansın alanı kavramların alanı değildir. Kavramlar sözcükler yoluyla zihin yoluyla kavranırlar. Ancak dans, sözcüklerin değil algıların, hareket yoluyla göz tarafından algılanan algıların alanıdır. ${ }^{35}$ Örneğin Cohen bir koreografin ayın dünyaya uzaklığı ya da Kant'ın kategorik buyruğu konusunda bir dans hazırlamakta zorlanabileceğini dile getirir, hatta dansta kayınvalidenin olmadığını alıntılar. Çünkü tüm bu kavramlar ve olgular sözcüklerle daha iyi ifade edilirler. Ancak dansın aracı insan hareketidir. Dans olgularla ya da fikirlerle değil, hareket halindeki insanlarla ilgilenir. ${ }^{36}$ Yani dansın temeli harekettir ve hareket bize duygular ve karakterlerle ilgili bilgi verir. İşte bu yüzden bir koreograf ayın dünyaya uzaklığıyla ilgili değil ama aya ilişkin hisleri hakkında bir dans tasarlayabilir. Ya da kendi kayınvalidesinin

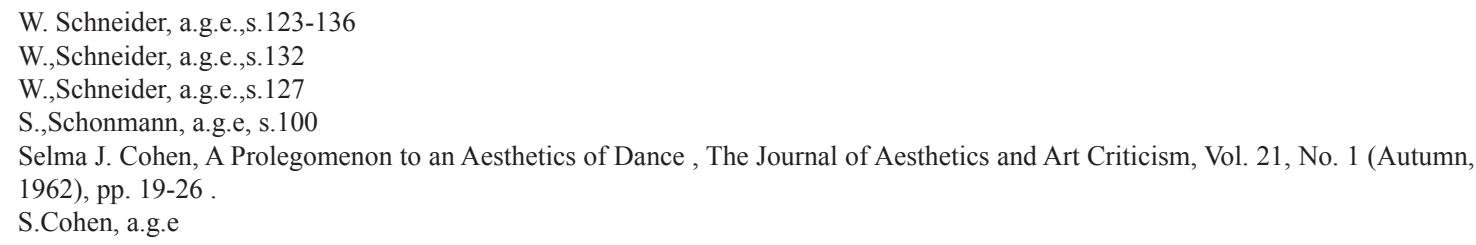


kendisinde uyandırdığı hisler üzerine dans hazırlayabilir. Hatta Kant'ın kavramları hakkında da eğer bu kavram onda bir duygu yaratıyorsa bir dans yapabilir ama bu fikir ya da olguya ilişkin bir hissi yoksa hakkında dans edeceği bir şey de yoktur. Kısaca koreografın bir dans gösterisi hazırlarken ilgilendiği, karakter ve duygu niteliğinin imgeleridir. ${ }^{37} \mathrm{Bu}$ durumda genç seyirciler için ölüm ya da Tanrı gibi tabu olan zor konuları işlemek isteyen bir koreograf da doğal olarak imgeler üzerine yoğunlaşacaktır. Böylelikle aslında genç seyirci için bilinmeyen, korku uyandıran ya da kavranması zor olan konular bir dans performansının oluşum aşamasında filtrelenir ve dans yoluyla genç seyircinin gündemine taşınır. Böylelikle hem genç seyircinin bu konudaki hayal gücü imgeler yoluyla harekete geçirilir, hem de yetişkinler tarafından belirlenmiş olan kavramların sahne üzerinde doğrudan temsili yerine, doğru göstergelerle genç seyirci kendi hayal dünyasındaki imgelerle düşünmeye sevk edilmiş olur.

\section{Sonuç}

Sonuç olarak çocuk ve gençler için yapılan teatral etkinliklerde sanatsal niteliğin arttırılmasına yönelik arayışlar, yeni ifade biçimlerinin ve anlatım olanaklarının keşfini zorunlu kılar. Bu yeni arayışlar genç seyircilerin yetişkin seyircilerden farklı özelliklere sahip olması sebebiyle ayrı bir araştırma konusu olduğu gibi aynı zamanda yetişkinliklerin inisiyatifiyle gelişen başlı başına bir sorumluluk alanıdır. Bir çalışma alanı olarak kendi içinde böylesi bir zorluğu barındıran gençlik tiyatrosu aynı zamanda çağın koşullarında değişen ve gelişen sanat anlayışını da takip etmek zorundadır. Tüm sanat disiplinleri arasında geçişkenlik artıp sınırlar incelirken ortaya konan bu çok disiplinli sanat eseri, seyircisiyle kurduğu ilişkide sınırları, keşfedilmemiş olana doğru zorlar. Bu durumda esetik deneyim salt felsefenin konusu olmaktan çıkıp psikoloji, sosyoloji, nörobilim ve başka daha pek çok bilimin ışı̆̆ında yeni verilerle yeniden tanımlanmaya çalışılır. Sahne sanatları açısından önemli olan gelişme, estetik deneyimi oluşturan duyularımızın alanının yapılan nitel çalışmalarla sanılandan daha geniş olduğunun kanıtlanmış olmasıdır. Yani estetik deneyim sadece görme ve işitme duyularımızla oluşmaz. En az onlar kadar önemli olan bu deneyime eşlik eden kinestetizi duyumuzun varlı̆̆ıdır. $\mathrm{Bu}$ durumda ritüellerden performatif dansa uzanan binlerce yıla yayılan bir sürede dansın insanoğlu için (hem seyirci hem katılımcı olarak) vazgeçilmezliği bilimsel olarak da desteklenmiş olur. O halde dans, bedenler yoluyla farklı estetik deneyimler yaşatabilecek yetiye sahiptir.

Günümüzde de dansın bu gücü farklı disiplinlerdeki sanat dallarında seyirciye yaşatılacak deneyimi kuvvetlendirmek ve çeşitlendirmek için kullanılmaktadır. Bu açıdan gençlik tiyatrosunun kendine has dinamikleri olsa da genel olarak son yıllarda dans dünyasında yaşanan gelişmeler dansın gençlik tiyatrosundaki yeri ve önemini ortaya çıkarmaya yardımcı olur. Günümüz dans dünyasının kendi sınırlarını dahi yıkmaya çalışan dinamiği genç seyirciler için yapılan etkinliklerde farklı arayışlara cevap olacak niteliktedir. Bu nedenle dans; ifade edilemeyeni ifade edebildiği, örtük anlamlara ulaşabildiği, seyircinin hayal gücünü kışkırttığı ve başka hiçbir sanat biçiminin harekete geçiremediği kinestezi duyusunu harekete geçirdiği için genç seyircinin yaşayacağı estetik deneyime katkı sağlar. Ayrıca dansın bilimsel verilerle de desteklenen bu potansiyeli gençlik tiyatrosunda kemikleşmiş bazı yargıları ortadan kaldırma gücüne sahiptir. Örneğin başı-sonu olan bir öykünün varlığı, soyut çalışmaların seyirci tarafından kavranamayacağı endişesi ya da daha da önemlisi teatral bir deneyimin bir şey öğretme gerekliliği gibi. Bu çalışmada konu edilen ve önceki bölümlerde daha da ayrıntılı incelenen dansın sahip olduğu bu dinamikler ülkemizde gençlik tiyatrosunun ifade olanaklarının zenginleştirilmesi için dansın nitelik, nicelik ve kapsam anlamında gelişmesi ve yaygınlaşması gerekliliğini ortaya koyar.

37 S.Cohen, a.g.e 


\section{Kaynakça}

Cohen S. J. (1962). A prolegomenon to an aesthetics of dance. The Journal of Aesthetics and Art Criticism 21 (1), 19-26 .

Cupchik C. G. (2002). The evolution of psychical distance as an aesthetic concept. Culture Psychology, $8(2), 155-187$.

Foster S. L. (2008). Movement's contagion: the kinesthetic 1mpact of performance. Cambridge Companion To Performance Studies, 12.

Geçtan E.(1984). Çağdaş yaşam ve normal dişı davranışlar. İstanbul: Maya Yayınları.

Langer S.(1983). Virtual Powers, What Is Dance?, Roger Copeland \&Marshall Cohen (Ed.), New York: Oxford Universty Press

Martin J.(1933). The modern dance, New York: A Dance Horizons Book Princton Book Company.

McFee G. (1992). Understanding dance, London: Routledge.

Montero, B. (2006). Proprioception as an aesthetic sense. The Journal of Aesthetics and Art Criticism, 64 (2), 231-242.

Naversen, R. (2001). Scenografic distance, Federation of Theater Research-IFTR ve Tradition and Innovation in Theater Design, Polonya.

Reason M. ve Reynolds D.(2010). Kinesthesia empathy and related pleasures: An inquiry into audience experience, Dance Research Journal, 42.

Schneider, W. (2005). Çocuklar için tiyatro. İstanbul: Mitos yayınları.

Schonmann S. (2006). Theatre for children and young people: Images and observations. Netherland: Springer.

Smith M. (1984). Kinesthetic communication in dance. Dance Research Journal, 16 (2), 19-22.

Tunalı, İ. (1989). Estetik. İstanbul: Remzi Kitabevi

Wigman M. (2009). Modern dansin felsefesi, Yirminci Yüzyılda Dans Sanatı 'Kuram ve Pratik’ (Yayına Haz.) Şebnem Selışık Aksan ve Gurur Ertem, İstanbul: Boğaziçi Üniversitesi Yayınları

Wildschut L. (2004). How children experinece watching dance?. Danswetenschap in Nederland, 3, 86-99.

Van Heeswijk L. (2010). The relation between dance, music and expectation choreographing surprise. Thesis MA Theatre Studies University, Utrecht.

www.watchingdance.org

http://www.termbank.net/psychology/3355.html 